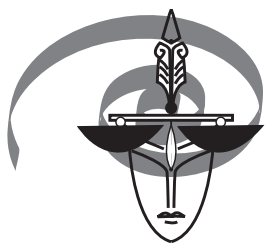

\title{
EUROPEAN
}

Volume $8 \cdot 2014 \cdot$ Number 2 (28)

DOI: 10.2478/ep-2014-0006

Marcin Gołaszewski*

\section{Polygraph Examination of Pregnant Women: Dilemmas and Recommendations}

Key Words: polygraph, pregnancy, examination

\section{Introduction}

Practice of polygraph examinations may require that experts subject a pregnant woman to such an examination, with e.g. state security in mind or due to a burning need of verifying information that is significant for the health and life of others. Sometimes expecting women themselves insist on being examined, for example, when they apply for a job, want to be enrolled in uniformed services, or try to acquire exculpatory evidence in a criminal procedure. Can a pregnant woman be subjected to a polygraph examination? Every such procedure requires informed consent of the examinee, pregnant women included. No other questions related to this highly special group of examinees are defined by law. Neither the standards of the American Polygraph Association, being

\footnotetext{
"marcin.golaszewski@wp.pl
} 
the world's largest professional organisation, nor of the ASTM International (American Society for Testing and Materials), being a worldwide standardisation organisation, envisage any detailed regulation in the area. ${ }^{1}$ Similarly, literature on the subject holds no proofs on the psychophysiology of a pregnant woman posing a significant obstacle in conducting such an examination. Although according to a custom prevalent e.g. in Poland the time of pregnancy is not suitable for such a procedure, the problem has not been analysed in detail. It seems that every case requires an individual approach, while generally there are no ethical or legal obstacles that would unconditionally rule out the possibility of subjecting pregnant women to polygraph examinations. What remains are technical questions, especially those related to the need of sitting motionlessly throughout the examination, and placement of the pneumograph pipes on the body of the examinee. Another additional encumbrance in advance pregnancies can be the movements of the foetus that are independent of the examinee's will. An experiment was conducted, especially with a view to technical circumstances, to decide whether a woman in advanced pregnancy can be successfully examined on a polygraph.

\section{Description of the experiment}

In July 2013, two Polish certified experts, including the author of the article, conducted experimental tests on a woman in the eighth month of pregnancy (figure 1). Technologies Inc. (Paragon) and Lafayette Instrument Co. (LX 4000) computer polygraph systems, were used for the study.

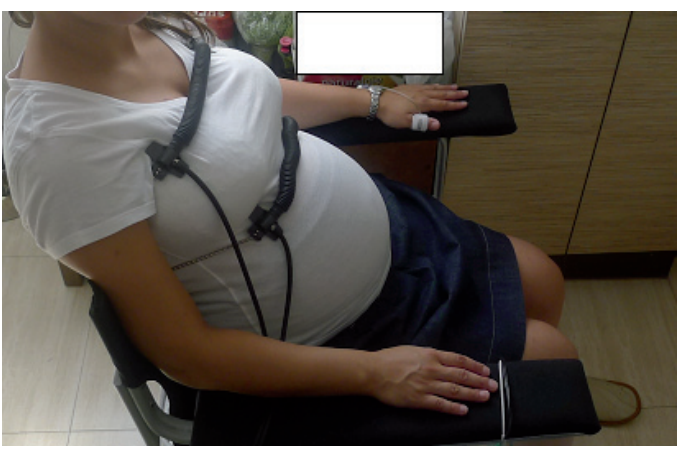

Fig. 1. A pregnant woman with Paragon (Limestone Tech) polygraph sensors.

\footnotetext{
${ }^{1}$ See: American Polygraph Association, Model Policy for the Evaluation of Examinee Suitability for Polygraph Testing, [online], http://www.polygraph.org/files/5_pg_model_policy_for_the_ evaluation_of_examinee_suitability_for_polygraph_testing.pdf [accessed on 29.07.2013]. More on APA standards: M. Gołaszewski, Wspótczesne standardy badań poligraficznych, Agencja Bezpieczeństwa Wewnętrznego, Warszawa 2013.
} 
The examinee's pressure before and during testing did not diverge from the norm. Nor did the examinee complain about the arm sleeve pumped up to $60 \mathrm{mmHg}$ for the duration of successive tests lasting from 3 to $5 \mathrm{~min}$. Alternatively, the sleeve was also placed on the thumb. As the examination forced sitting on the chair, and pregnant women need to pass urine more often, a 10-minute break was ordered after every 30 min of the experiment. The P1 pneumograph (lower) was first placed between the chest and the abdomen (Fig. 2), and in the second phase of the experiment - directly on the abdomen (Fig. 3). The experiment primarily made use of the classical peak of tension (POT) tests with a number.

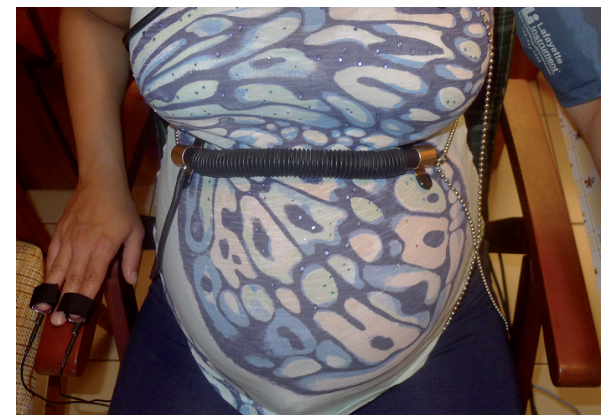

Fig. 2. Pneumograph between the chest and abdomen.

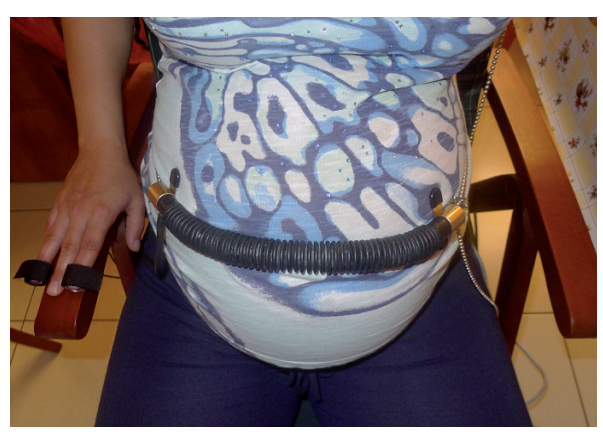

Fig. 3. Pneumograph on the abdomen (Lafayette).

Significant changes of physiological reactions of the subject were observed during the examination whenever she felt the child moving. These were primarily reactions that were more closely connected to the emotional reactions that a future mother displays in such moments than ones resulting from the movements themselves. The respondent informed about them with an agreed gesture both during the test and after the completion of registering examination data. Changes in the reactions are best seen in the sudden increase of the GSR amplitude, and also in the breathing cycle (Fig. 4).

Small, downright insignificant, changes in the recording from the moment sensor (Fig. 5) may occur, but this is not a rule. Clearer changes related to foetal activity may be noticed usually in the P1 pneumograph curve (Fig. 6 and 7) independent of sensor placement (on or above the abdomen). This is worth comparing with the P2 pneumograph curve. Special care must be paid while assessing the breathing parameter. 


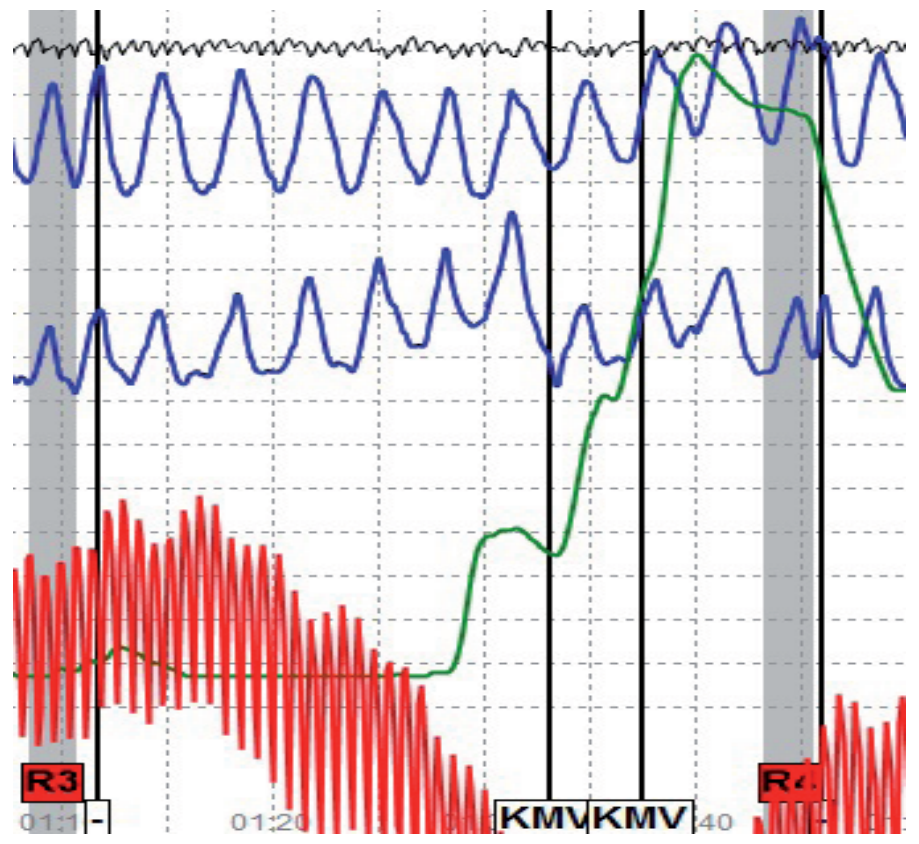

Fig. 4. Changes in a electrodermal activity and breathing curves in reaction to foetus movements.

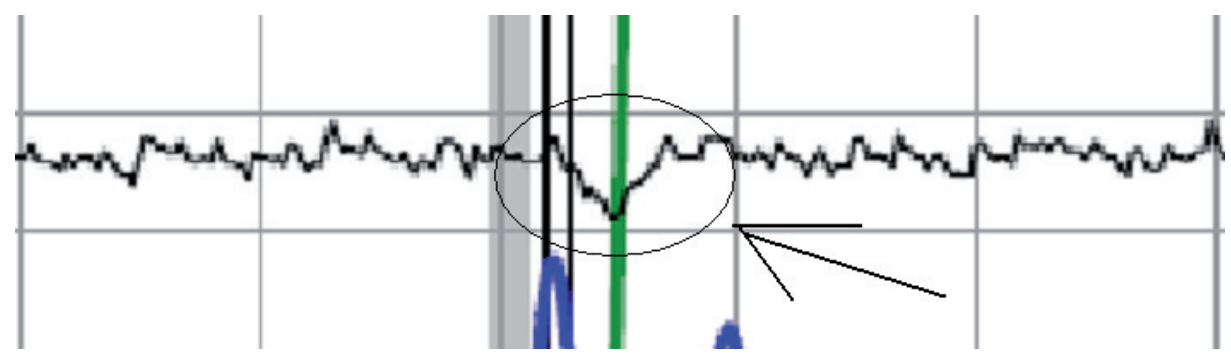

Fig. 5. Minimal changes in the recording from the movement sensor during child movements sensed by the examinee. 


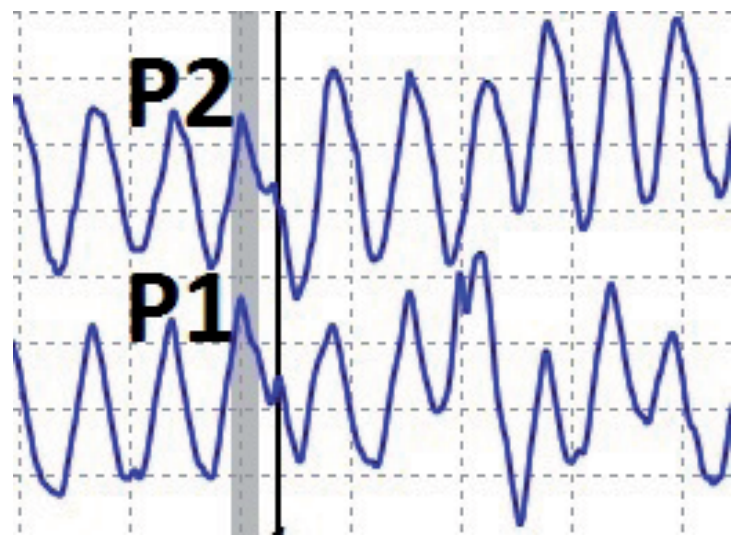

Fig. 6. Changes in the P1 pneumograph curve resulting from the child kicking in the womb.

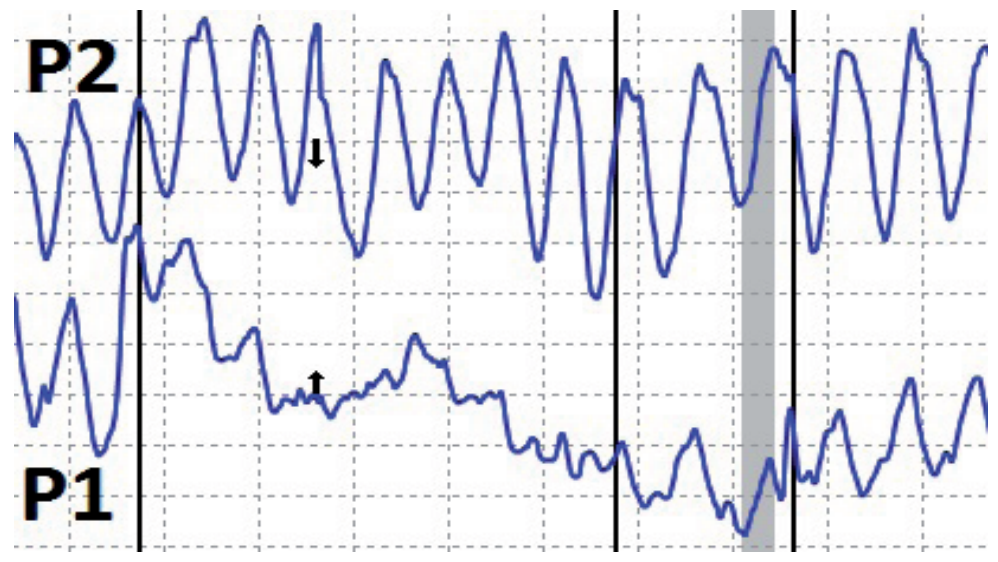

Fig. 7. Highly visible deformities of the curve from the P1 breathing sensor in pregnant women caused by child movements.

Despite the non-standard polygram recordings resulting from the child moving in the womb discussed above, the charts of physiological reactions registered allowed fully meaningful assessment of answers to the questions, and identification of the most significant test stimulus. It was also possible to collect charts without any disturbance from movements. Polygrams of an 8 -months-pregnant woman were similar to that of a regular examinee (see: Fig. 8 and 9). 


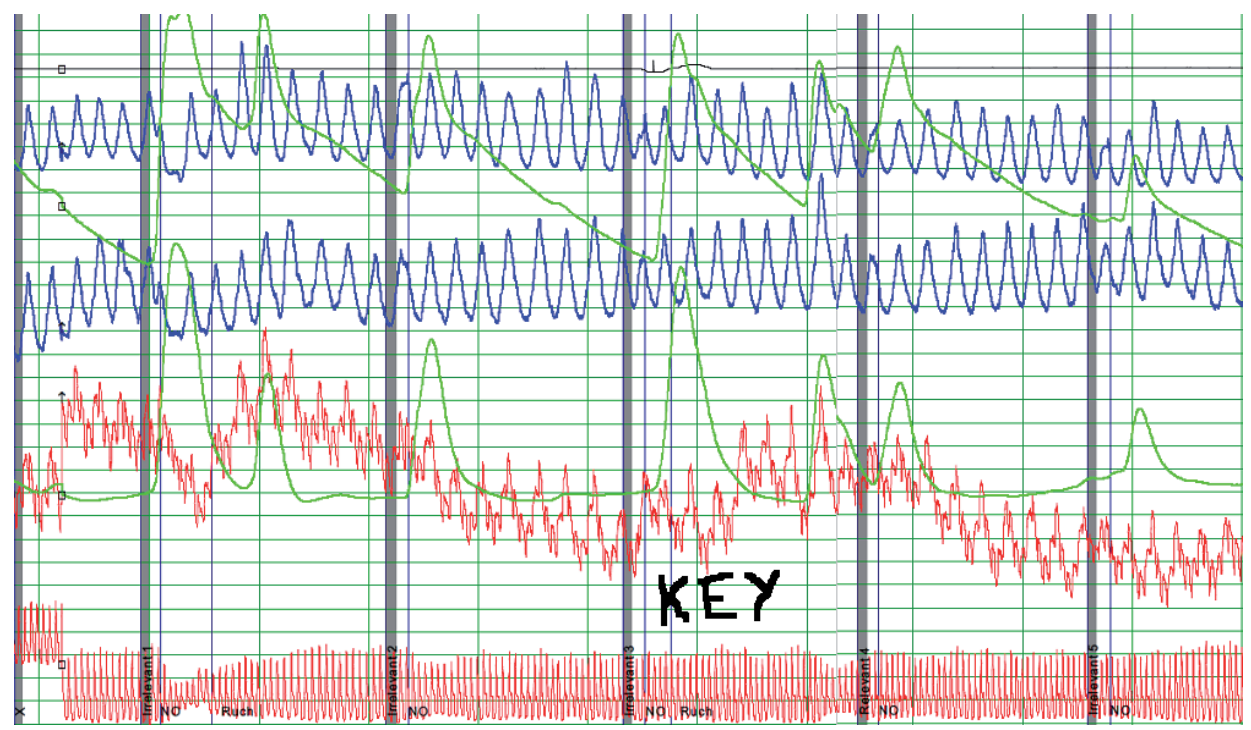

Fig. 8. A fragment of the number test conducted on a pregnant woman with a Paragon polygraph manufactured by Limestone (the key stimulus is question No. 3, and peak tension is clearly visible).

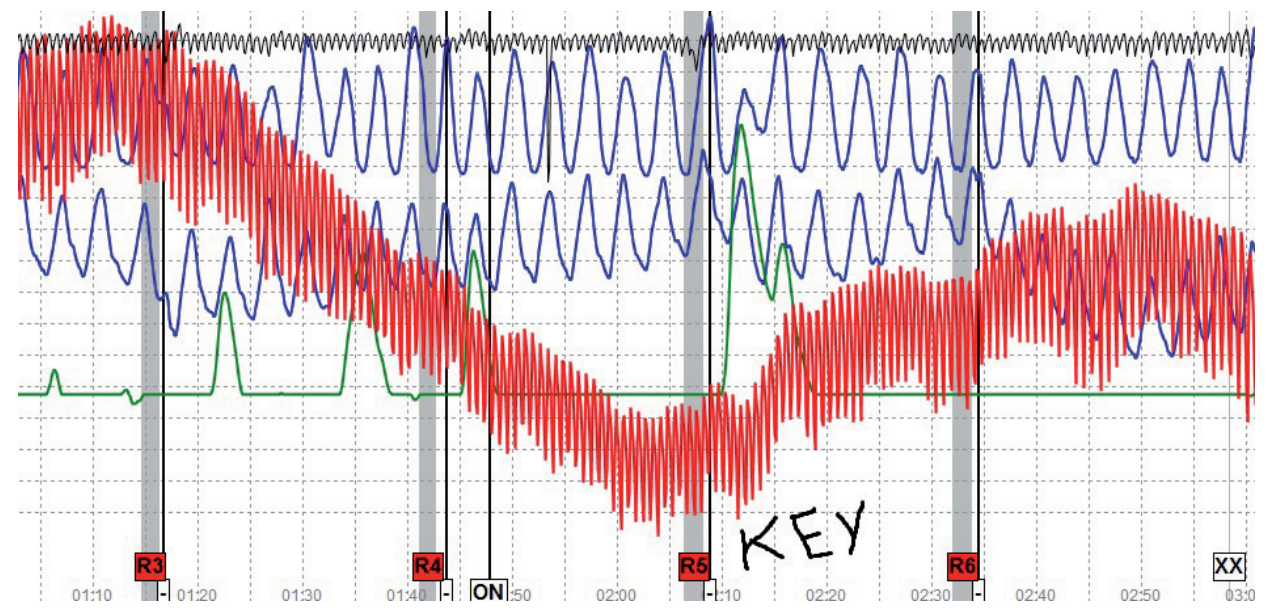

Fig. 9. A fragment of the number test conducted on a pregnant woman by another expert with an LX4000 polygraph from Lafayette Instruments. 
It is worth quoting here an interesting experiment that was conducted on 9th May 2014, when Raymond Nelson, current President Elect of the American Polygraph Association presented polygrams of 10 examinees, whose number included pregnant and non-pregnant women, and men, during a meeting with Polish polygraph experts in Warsaw. None of the participants was capable of discriminating correctly which charts concerned which categories of examinees. This is another proof corroborating that there are generally no significant differences in the course of the registered physiological reactions between pregnant women and other people. Still, even if such differences were present, one should not reject the possibility of conducting the study in advance, as the discovery of problematic behaviours based on polygrams is not the only goal of polygraph examinations. Equally important is the opportunity of acquiring more information from the examinee than with the use of other previously applied methods. This takes place during the interview preceding the tests, the conversation between the tests series, and in the phase of discussing the results of the examination.

With the above in mind, it can be assumed that if a pregnant woman expresses her informed consent to undergo a polygraph examination, there are no obstacles in performing such a procedure (especially in the relatively safest and least cumbersome second trimester of pregnancy). It is, however, worth to take into account the comments and recommendations presented further in this article.

\section{Comments and recommendations}

I. When should a pregnant woman not be subjected to a polygraph examina$\underline{\text { tion? }}$

1. When the pregnancy is compromised, and/or when there are any counter indications from the physician.

2. If the interview corroborates intense emotions of the potential examinee, and/or significant physical ailments (strong aches, weakness, etc.).

3. With too high or too low values of arterial blood pressure and heart rate (correct blood pressure ranges from 110/60 to $140 / 90 \mathrm{mmHg}$, yet small short lasting variations related to emotional stimulation are allowed. On the other hand, a heart rate increased by $15-20$ beats must be considered normal due to the volume of blood constantly growing in the woman's organism. 
II. Limitations and phenomena that must be taken into consideration while subjecting pregnant women to polygraph examinations

1. Avoiding strong stress.

- A pregnant woman is generally more sensitive to emotions because of the hormones.

- Coming first in a difficult situation is a short term reaction - vegetative stimulation of the organism in reaction to a stressor. Triggered later are conscious and unconscious mechanisms of coping with the situation. In Lazarus' stress-coping model, ${ }^{2}$ an event is not stressful in itself, and the sense of burden related to it is determined by the consequence assigned to the situation during the original cognitive assessment (being an answer to the question "What does it mean to me?"). ${ }^{3}$ An individual may assess the situation as harm, threat (anxiety reactions), loss (regret, sorrow), or challenge (mobilisation). The condition of a pregnant woman must be paid special attention to when the observed and declared fear is too great, or when the examinee endeavours so badly to have something explained or to have a favourable result of the examination that her emotional stimulation exceeds levels considered safe by common sense.

- Under the impact of stress, the concentration of cortisol and adrenaline, organic compounds commonly known as "stress hormones" is growing. Too high concentration of cortisol contributes to child malformations (including heart and the nervous system). In extreme conditions, there is a risk of miscarriage in the first trimester or, in a later period of the pregnancy, of a premature labour activity caused by too high level of adrenaline.

- A sudden and significant increase of blood pressure may lead to placental detachment. ${ }^{4}$

2. An increased exertion of the organism, tiredness, and sleepiness (especially in the first trimester), increased heart rate.

3. Consequences of distended matrix and abdomen:

- shifted centre of mass of the woman

- a greater burden on the muscles and joints; possible pain in the spine (also because of the loosening of the joints caused by the hormones).

\footnotetext{
${ }^{2}$ R.S. Lazarus, Psychological Stress and the Coping Process, McGraw-Hill, New York 1966.

${ }^{3}$ J. Krzyżanowska-Zbucka, Problemy emocjonalne kobiet $w$ okresie okotoporodowym, Fundacja Rodzić po Ludzku, Warszawa 2008, pp. 7-8.

${ }^{4}$ M. Puchowska, Stres w ciaży, Mamazone.pl, [online], http://www.mamazone.pl/artykuly/ ciaza-i-porod/uczucia/2010/stres-w-ciazy.aspx [accessed on 29.07.2013].
} 
- Need for more frequent urination, because of the pressure of the body of the uterus on the bladder.

4. Movements of the foetus:

- first sensed by the woman between the 16th and 22nd week of pregnancy

- uncoordinated, arhythmical movements including straightening up, stretching, sucking, catching, and kicking

- they may result in distortions of polygram curves, and in emotional reactions of the examinee.

III. General guidelines for a polygraph expert conducting an examination of a pregnant woman

1. Make sure whether the examination is necessary at the moment. Does it make sense to wait? If this is a routine employment procedure, try to convince the woman to postpone it till after the birth. Still, the future mother will have to spend at least a few months taking care of the newborn.

2. If an examination has been decided, try to perform it close to the place where the examinee lives so as to avoid long travel and additional anxiety caused by being far from home.

3. The room where the examination is conducted should be air-conditioned.

4. The entire examination should not exceed 2 or 3 hours, and an individual test series (chart) - no more than a few minutes.

5. At the beginning, ask about the general well-being, emotional state, and possible sleep disturbances within 24 hours before the examination.

6. As always, build up an atmosphere of tranquillity and trust for the expert. Try to be even more tactful than usually.

7. Do not stretch the pneumographs excessively.

8. Pump up the cardio sleeve to the maximum of $65 \mathrm{mmHg}$.

9. Make frequent breaks (pay attention to physiological needs, and also to the fact sitting for a longer spell of time aggravates the back ache of a pregnant woman).

10.During the breaks, regularly monitor blood pressure and pulse of the examinee.

\section{References}

American Polygraph Association, Model Policy for the Evaluation of Examinee Suitability for Polygraph Testing, [online], http://www.polygraph.org/ 
files/5_pg__model_policy_for_the_evaluation_of_examinee_suitability_for_ polygraph_testing.pdf [accessed on 29.07.2013].

Gołaszewski M., Ibek A., Widacki M., Współczesne standardy badań poligraficznych, ed. M. Gołaszewski, Agencja Bezpieczeństwa Wewnętrznego, Warszawa 2013.

Krzyżanowska-Zbucka J., Problemy emocjonalne kobiet $w$ okresie okołoporodowym, Fundacja Rodzić po Ludzku, Warszawa 2008.

Lazarus R.S., Psychological Stress and the Coping Process, McGraw-Hill, New York 1966.

Puchowska M., Stres w ciaży, serwis Mamazone.pl, [online], http://www. mamazone.pl/artykuly/ciaza-i-porod/uczucia/2010/stres-w-ciazy.aspx [accessed on 29.07.2013]. 